\title{
PREVALENSI PASIEN BARU KUSTA DI RSUD BUDHI ASIH TAHUN 2015 SAMPAI TAHUN 2018
}

\author{
*Zuraida ${ }^{1)}$, Sofiyatun Nurhidayah ${ }^{1)}$ \\ ${ }^{1}$ Program Studi Analis Kesehatan, Fakultas Kesehatan, Universitas Mohammad Husni Thamrin \\ Correspondence author: Zuraida, nurhasan.aida@gmail.com, Jakarta, Indonesia
}

\begin{abstract}
ABSTRAK
Kusta adalah penyakit yang disebabkan oleh bakteri Mycobacterium leprae. Kasus baru penyakit kusta masih menjadi masalah kesehatan masyarakat terutama di negara berkembang, seperti di Indonesia dengan prevalensi pada tahun 2017 sebesar 0,70 kasus/10.000 penduduk dan angka penemuan kasus baru sebesar 6,08 kasus per 100.000 penduduk. Kusta menjadi masalah kesehatan karena penyakit kusta merupakan penyakit menular dan kronis. Penelitian ini bertujuan untuk mengetahui persentase pasien baru kusta dengan BTA MH positif di RSUD Budhi Asih pada tahun 2015-2018. Sampel adalah data rekam medik pasien baru kusta rawat jalan yang melakukan pemeriksaan BTA MH di RSUD Budhi Asih tahun 2015 - 2018 sebanyak 290 pasien. Berdasarkan hasil penelitian, diperoleh pasien baru kusta dengan BTA MH positif $103(35,52 \%)$ pasien, $73(70,87 \%)$ pasien berjenis kelamin laki-laki, 58(56,31\%) pasien dengan usia 20-50 tahun, 115(39,66\%) pasien tipe PB dan $175(60,34 \%)$ pasien tipe MB. Kesimpulan yang diperoleh dari penelitian ini menyatakan bahwa persentase pasien baru kusta di RSUD Budhi Asih adalah sebesar 103(35,52\%). Pasien baru kusta terbanyak berjenis kelamin laki-laki,usia produktif, tipe kusta MB . Perlu peningkatan pengawasan oleh sektor kesehatan dalam rangka pencegahan dan penularan penyakit kusta.
\end{abstract}

Kata kunci : Mycobacterium leprae, basil tahan asam,pemeriksaan laboratorium.

\begin{abstract}
Leprosy is a disease caused by the bacteria Mycobacterium leprae. New cases of leprosy are still a public health problem, especially in developing countries, such as in Indonesia with a prevalence in 2017 of 0.70 cases $/ 10,000$ population and a new case finding rate of 6.08 cases per 100,000 population. Leprosy is a health problem because leprosy is a contagious and chronic disease. This study aims to determine the percentage of new leprosy patients with positive BTA MH at Budhi Asih Regional Hospital in 2015-2018. The sample is the medical record data of new outpatient leprosy patients who examined the BTA MH at Budhi Asih Hospital in 2015-2018 totaling 290 patients. Based on the results of the study, it was found that 103 (35.52\%) patients with leprosy new leprosy (35.52\%) patients, 73 (70.87\%) male patients, $58(56.31 \%)$ patients aged 20-50 years, 115 (39.66\%) patients with PB type and 175 (60.34\%) patients with MB type. The conclusion obtained from this study states that the percentage of new leprosy patients at Budhi Asih Regional Hospital is 103 (35.52\%). Most new patients with leprosy are male, of productive age, and the type of leprosy is MB. It is necessary to increase supervision by the health sector in the context of preventing and spreading leprosy.
\end{abstract}

Key words: Mycobacterium leprae, acid-resistant bacilli, laboratory examination. 


\section{PENDAHULUAN}

Istilah kusta berasal dari bahasa Sansekerta, yakni kushta berarti kumpulan gejala-gejala kulit secara umum. Penyakit kusta atau lepra disebut juga Morbus Hansen, sesuai dengan nama yang menemukan kuman yaitu Dr.Gerhard Armauwer Hansen tahun 1874 sehingga penyakit ini disebut Morbus Hansen. Penyakit Hansen adalah sebuah penyakit kronis yang disebabkan oleh bakteri Mycobacterium leprae (M. leprae). Penyakit ini adalah tipe penyakit granulomatosa pada saraf tepi dan mukosa dari saluran pernapasan atas; dan lesi pada kulit adalah tanda yang bisa diamati dari luar. Bila tidak ditangani, kusta dapat sangat progresif, menyebabkan kerusakan pada kulit, saraf-saraf, anggota gerak, dan mata (Andareto, O, 2015:182). Rasa takut yang berlebihan terhadap kusta (leprophobia) dan pengertian yang keliru terhadap penyakit kusta juga akan memperberat penemuan dan penyembuhan penderita kusta (Depkes RI, 2007).

Kusta juga masih merupakan masalah kesehatan di negara berkembang termasuk Indonesia, walaupun Indonesia dapat mengeliminasi kusta secara nasional pada pertengahan tahun 2000 dengan catatan di beberapa daerah tertentu prevalensi kusta masih cukup tinggi (Dep.Kes R.I., 2007). World Health Organization (WHO) menempatkan Indonesia sebagai negara ketiga terbesar ketiga di dunia soal jumlah penderita kusta. Dalam hal ini, Indonesia di posisi ketiga setelah India dan Brazil. Jumlah kasus baru kusta di dunia pada tahun 2015 adalah sekitar 210.758. Dari jumlah tersebut paling banyak terdapat di regional Asia Tenggara (156.118) diikuti regional Amerika (28.806) dan Frika (20.004), dan sisanya berada di regional lain (Pusat Data dan Informasi Kementerian Kesehatan RI, 2018:2).

Indonesia telah mencapai status eliminasi kusta, yaitu prevalensi kusta $<1$ per 10.000 penduduk $(<10$ per 100.000 penduduk), pada tahun 2000.Setelah itu Indonesia masih bisa menurunkan angka kejadian kusta meskipun relatif lambat.

Angka prevalensi kusta di Indonesia pada tahun 2017 sebesar 0,70 kasus/10.000 penduduk dan angka penemuan kasus baru sebesar 6,08 kasus per 100.000 penduduk. Ada provinsi yang prevalensinya masih di atas 1 per 10.000 penduduk (Pusat Data dan Informasi Kementerian Kesehatan RI, 2018:3). Pada anak,selama periode 2013-2017, angka penemuan kasus baru pada tahun 2013 merupakan yang tertinggi yaitu sebesar 11,88 per 100.000 penduduk (Pusat Data dan Informasi Kementerian Kesehatan RI, 2018:4) Jumlah penderita kusta terbanyak terdapat di Provinsi Jawa Timur pada periode tahun 20152017, namun dengan penurunan penderita sebesar 15,95\%,sedangkan provinsi yang mengalami kenaikan jumlah penderita paling tinggi dalam kurun waktu 2015-2017 terdapat di provinsi Maluku sebesar 102,84\% ( Pusat Data dan Informasi Kementerian Kesehatan RI, 2018:7)

Pada tahun 2018 sekitar 15 ribu kasus baru.Tercatat kasus kusta tersebar di 7.548 desa atau kelurahan, mencakup wilayah kerja 1.975 Puskesmas di 341 kabupaten/kota seluruh Indonesia. kusta masih tersebar di 7.548 desa/kelurahan/kampung yang ada di 341 kabupaten/ kota di Indonesia.. Kasus kusta terbanyak terjadi di wilayah Indonesia timur seperti Papua, Papua Barat, Maluku, dan Maluku Utara. 
Tercatat provinsi-provinsi Sulawesi Tenggara, Sulawesi Selatan, Sulawesi Tengah, Sulawesi Barat, Gorontalo, Sulawesi Utara, Maluku, Maluku Utara, Papua, dan Papua Barat belum eliminasi kasus penyakit ini (www.Depkes.go.id, 2018). Di Provinsi DKI Jakarta dilaporkan terdapat 344 kasus baru,terdiri dari kasus tipe Multi Basiler sebanyak 306 dan tipe Pausi Basiler sebanyak 38 kasus.Angka penemuan kasus baru (NCDR/New Case Detection Rate) per 100.000 penduduk adalah 3,25 (Data dan Informasi ,Profil Kesehatan Indonesia, 2018:Tabel 6.19)

Diagnosa klinis ditegakkan dengan melakukan pemeriksaan kulit secara lengkap dengan menemukan tanda-tanda terserangnya syaraf tepi berupa gejala hipestasia, anesthesia, paralisis pada otot dan ulkus tropikum. Diagnosa kusta tipe lepromatosa (multibasiller) ditegakkan dengan ditemukannya bakteri tahan asam pada sediaan yang diambil dengan melakukan insisi pada kulit. Pada kusta tipe tuberkuloid (paucibaciller) jumlah basil kemungkinan sangat sedikit sehingga sulit ditemukan pada pemeriksaan (Yudied,dkk., 2008:21).

Suatu kenyataan bahwa sebagian besar penderita kusta adalah dari golongan ekonomi lemah. Perkembangan penyakit kusta pada diri penderita bila tidak ditangani secara cermat dapat menimbulkan cacat dan keadaan ini menjadi halangan bagi penderita kusta dalam kehidupan bermasyarakat untuk memenuhi kebutuhan sosial ekonomi mereka, juga tidak dapat berperan dalam pembangunan bangsa dan negara (Setyoko,dkk., 2012:39).

Perilaku sebagai faktor yang sangat berpengaruh dan menentukan derajat kesehatan atau status kesehatan individu dan masyarakat, termasuk dalam hal ini penolakan status penyakit kusta. Beberapa penelitian yang telah dilakukan memberikan gambaran bahwa penyakit lepra adalah penyakit keturunan. Ini disebabkan bahwa kurangnya pengertian dan pengetahuan masyarakat tentang penyakit kusta .

Penolakan penderita kusta terhadap penyakit yang diderita berdasarkan aspek kepercayaan ( Rahman,A.M., Aibidin,S., Abdul,R.A., 2013:100). Menurut penelitian yang telah di lakukan oleh Herlina Soumilena,Standy Soeliongan, Velma Buntuan (2014) pada Gambaran pemeriksaan mikroskopik basil tahan Asam pada pasien diagnosa klinik lepra di poli penyakit kulit dan kelamin di Manado hasilnya dari 20 sampel yang diperiksa di temukan 11 sample positif BTA dan 9 sampel negatif BTA,pria lebih banyak dibanding wanita.

RSUD Budhi Asih adalah salah satu rumah sakit daerah yang ada di wilayah Jakarta Timur yang memberikan pelayanan kesehatan kepada masyarakat luas.Salah satu nya adalah pelayanan terhadap pasien kusta.

Berdasarkan latar belakang di atas maka penulis tertarik melakukan penelitian untuk mengetahui Persentase Suspek kusta dengan BTA positif di RSUD Budhi Asih tahun 2018. 


\section{METODE PENELITIAN}

Penelitian ini merupakan penelitian deskriptif dengan menggunakan data sekunder pada pasien baru kusta rawat jalan di RSUD Budhi Asih dari bulan Januari 2015 sampai dengan Desember 2018.Penelitian dilakukan pada bulan Juli 2019 di Instalasi Laboratorium RSUD Budhi Asih ,Jakarta.Populasi pada penelitian ini adalah seluruh data pasien baru kusta rawat jalan di RSUD Budhi Asih dari bulan Januari 2015 sampai dengan Desember 2018 . Sampel yang digunakan pada penelitian ini adalah data pasien baru kusta rawat jalan yang melakukan pemeriksaan BTA MH di RSUD Budhi Asih dari bulan Januari 2015 sampai dengan Desember 2018. Dari populasi penelitian dipilih sebagai sampel penelitian dengan kriteria inklusi dan ekslusi sebagai berikut : Kriteria Inklusi adalah data pasien yang melakukan pemeriksaan BTA MH tercatat data lengkap jenis kelamin, usia dan jumlah lesi. Kriteria Ekslusi adalah data pasien yang melakukan pemeriksaan BTA MH tidak terdapat data lengkap jenis kelamin,usia dan jumlah lesi.

Data pada penelitian ini didapat dengan melakukan pengumpulan data dengan tahap-tahap sebagai berikut:

1. Mengajukan surat permohonan izin untuk mengambil data rekam medik pasien penderita kusta di RSUD Budhi Asih.

2. Melakukan observasi di RSUD Budhi Asih untuk mengetahui berapa banyak pasien baru rawat jalan yang melakukan pemeriksaan BTA MH di RSUD Budhi Asih.

3. Melakukan pengumpulan data dari rekam medik pasien dengan BTA MH positif yang diperoleh di RSUD Budhi Asih

4. Data yang diperoleh disajikan dalam bentuk persentase.

Data yang telah diperoleh kemudian diolah/dihitung untuk mengetahui persentase penderita kusta.

Perhitungan dilakukan dengan membandingkan antara jumlah seluruh pasien baru kusta rawat jalan di RSUD Budhi Asih dengan jumlah seluruh pasien baru kusta BTA MH positif yang melakukan pemeriksaan laboratorium di RSUD Budhi Asih dari tahun 2015 sampai tahun 2018.

$\%=\frac{x}{n} \times 100 \%$

Keterangan:

$\%$ : Proporsi

$\mathrm{x}$ : Jumlah seluruh pasien baru kusta dengan BTA positif

$\mathrm{n}$ : Jumlah seluruh data pasien baru kusta rawat jalan 


\section{HASIL DAN PEMBAHASAN}

\section{Hasil Penelitian}

\section{Persentase pasien baru kusta di RSUD Budhi asih tahun 2015 - 2018.}

Berdasarkan data hasil pemeriksaan terhadap pasien baru kusta rawat jalan yang melakukan pemeriksan BTA di RSUD Budhi Asih tahun 2015 sampai dengan tahun 2018 dapat terlihat pada tabel bawah ini :

Tabel 1

Hasil pemeriksaan BTA MH

\begin{tabular}{|c|c|c|c|c|c|}
\hline \multirow{3}{*}{ Variabel } & \multicolumn{4}{|c|}{ Jumlah \& Persentase (\%) } & \multirow{3}{*}{ Jumlah } \\
\hline & \multicolumn{4}{|c|}{ Tahun } & \\
\hline & 2015 & 2016 & 2017 & 2018 & \\
\hline \multirow{2}{*}{\multicolumn{6}{|c|}{$\begin{array}{c}\text { Hasil } \\
\text { Pemeriksaan } \\
\text { BTA MH }\end{array}$}} \\
\hline & & & & & \\
\hline Positif & $27(40,3 \%)$ & $16(22,9 \%)$ & $16(24,2 \%)$ & $44(50,5 \%)$ & $103(35,52 \%)$ \\
\hline Negatif & $40(59,7 \%)$ & $54(77,1 \%)$ & $50(75,8 \%)$ & $43(49,5 \%)$ & $187(64,48 \%$ \\
\hline Jumlah & $67(100 \%)$ & $70(100 \%)$ & $66(100 \%)$ & $87(100 \%)$ & $290(100 \%)$ \\
\hline
\end{tabular}

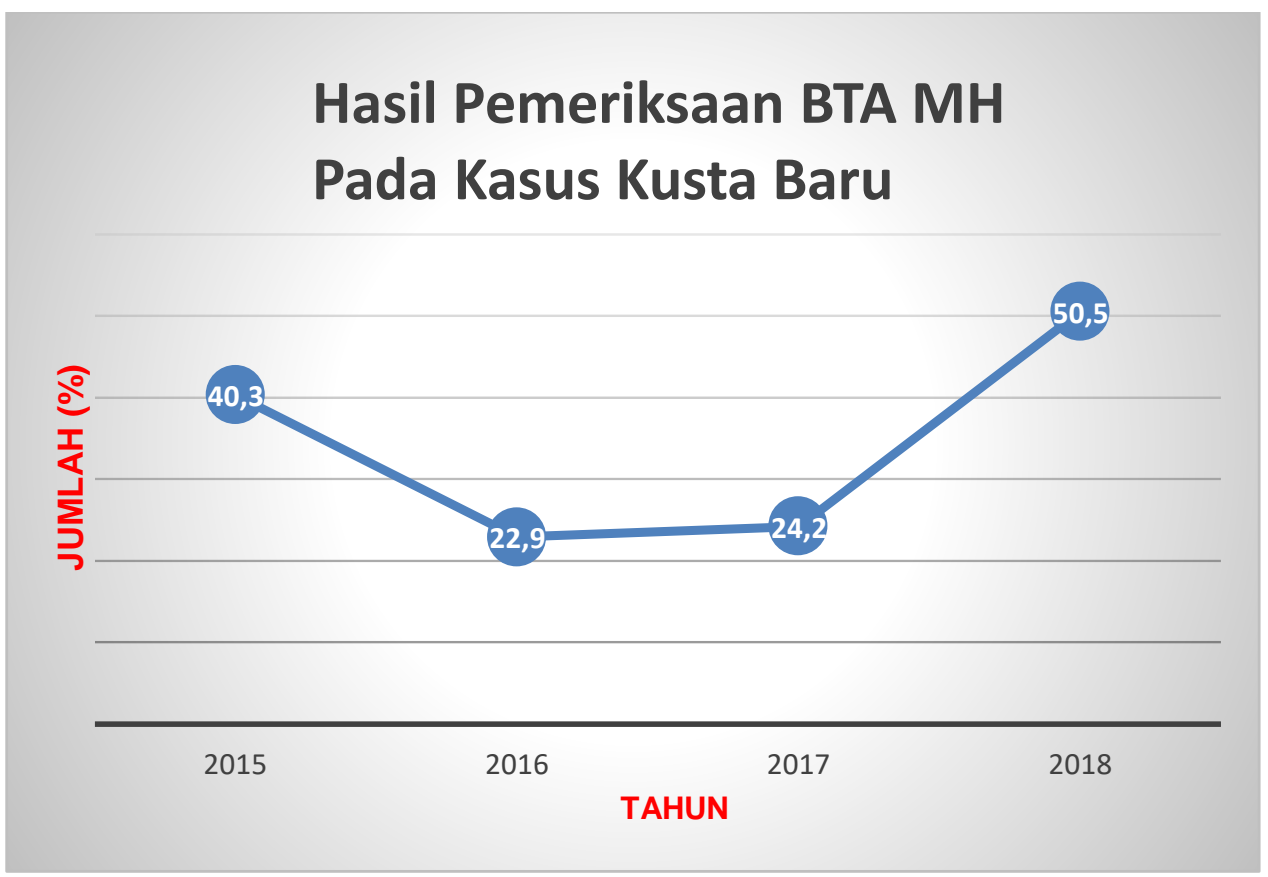

Gambar 1.

Persentase Hasil Pemeriksaan BTA MH Pada kasus Kusta Baru Tahun 2015 - 2018

Berdasarkan data di atas dapat diketahui bahwa dari tahun 2015 -2018 terdapat 290 pasien yang memeriksakan BTA MH di dapat 103(35,52\%) pasien dengan hasil BTA MH positif. 
Persentase pasien baru kusta dengan BTA MH positif di RSUD Budhi Asih tahun 2015 - 2018 berdasarkan jenis kelamin.

Berdasarkan penggolongan jenis kelamin dengan hasil pemeriksaan BTA MH positif di RSUD Budhi Asih dari tahun 2015 - 2018, dapat terlihat pada tabel hasil dibawah ini :

Tabel 2

Persentase pasien baru Kusta Dengan Hasil Pemeriksaan BTA MH Positif Berdasarkan Jenis Kelamin

\begin{tabular}{cccccc}
\hline \multirow{2}{*}{ Variabel } & \multicolumn{4}{c}{ Jumlah \& Persentase (\%) } & \multirow{2}{*}{ Jumlah } \\
\cline { 2 - 4 } & \multicolumn{3}{c}{ Tahun } & \\
\cline { 2 - 5 } & 2015 & 2016 & 2017 & 2018 & \\
\hline Jenis Kelamin & & & & \\
Laki - laki & $22(81,5 \%)$ & $11(68,8 \%)$ & $7(43,8 \%)$ & $33(75 \%)$ & $73(70,87 \%)$ \\
Perempuan & $5(18,5 \%)$ & $5(31,2 \%)$ & $9(56,2 \%)$ & $11(25 \%)$ & $30(29,13 \%)$ \\
\hline Jumlah & $27(100 \%)$ & $16(100 \%)$ & $16(100 \%)$ & $44(100 \%)$ & $103(100 \%)$ \\
\hline
\end{tabular}

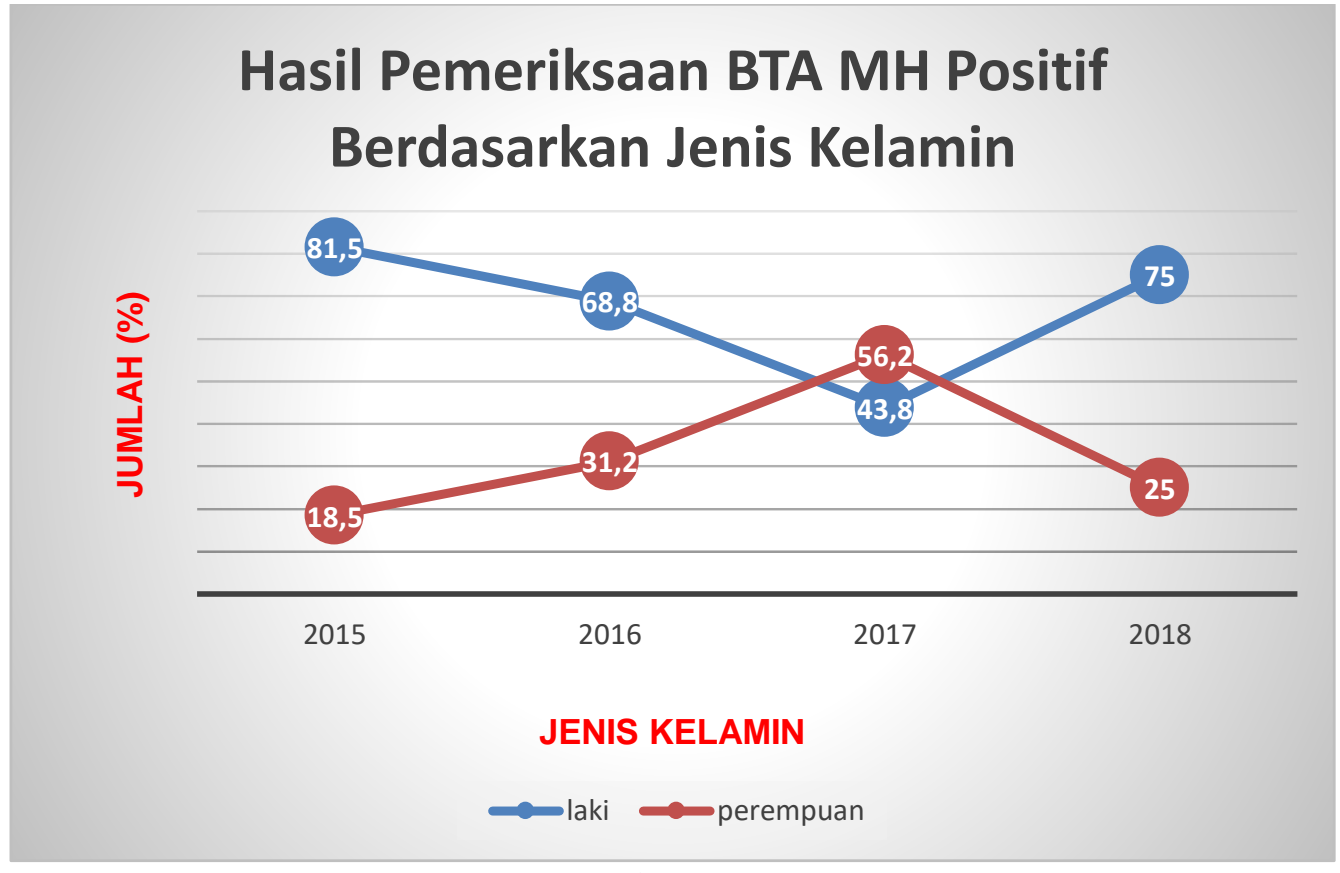

Gambar 2.

Persentase Pasien Baru Kusta dengan Hasil pemeriksaan BTA MH Positif Berdasarkan Jenis Kelamin

Berdasarkan data di atas dapat diketahui bahwa berdasarkan jenis kelamin dari tahun 2015 - 2018 dengan hasil BTA MH positif ,terbanyak didapatkan pada pasien dengan jenis kelamin kali-laki yaitu sebanyak 73(70,87\%)pasien. 
Persentase pasien baru kusta dengan BTA MH positif di RSUD Budhi Asih tahun 2015 - 2018 berdasarkan kelompok usia.

Berdasarkan penggolongan kelompok usia dengan hasil pemeriksaan BTA MH positif di RSUD Budhi Asih dari tahun 2015 - 2018, dapat terlihat pada tabel hasil dibawah ini :

Tabel 3

Persentase pasien baru Kusta Dengan Hasil Pemeriksaan BTA MH Positif Berdasarkan Kelompok Usia

\begin{tabular}{|c|c|c|c|c|c|}
\hline \multirow{3}{*}{ Variabel } & \multicolumn{4}{|c|}{ Jumlah \& Persentase (\%) } & \multirow{3}{*}{ Jumlah } \\
\hline & \multicolumn{4}{|c|}{ Tahun } & \\
\hline & 2015 & 2016 & 2017 & 2018 & \\
\hline Umur & & & & & \\
\hline$\leq 19$ & $5(18,52 \%)$ & $1(6,25 \%)$ & $0(0 \%)$ & $7(15,91 \%)$ & $13(12,62 \%)$ \\
\hline $20-50$ & $13(48,15 \%)$ & $9(56,25 \%)$ & $12(75 \%)$ & $24(54,54 \%)$ & $58(56,31 \%)$ \\
\hline$\geq 51$ & $9(33,33 \%)$ & $6(37,50 \%)$ & $4(25 \%)$ & $13(29,55 \%)$ & $32(31,07 \%)$ \\
\hline Jumlah & $27(100 \%)$ & $16(100 \%)$ & $16(100 \%)$ & $44(100 \%)$ & $103(100 \%)$ \\
\hline
\end{tabular}

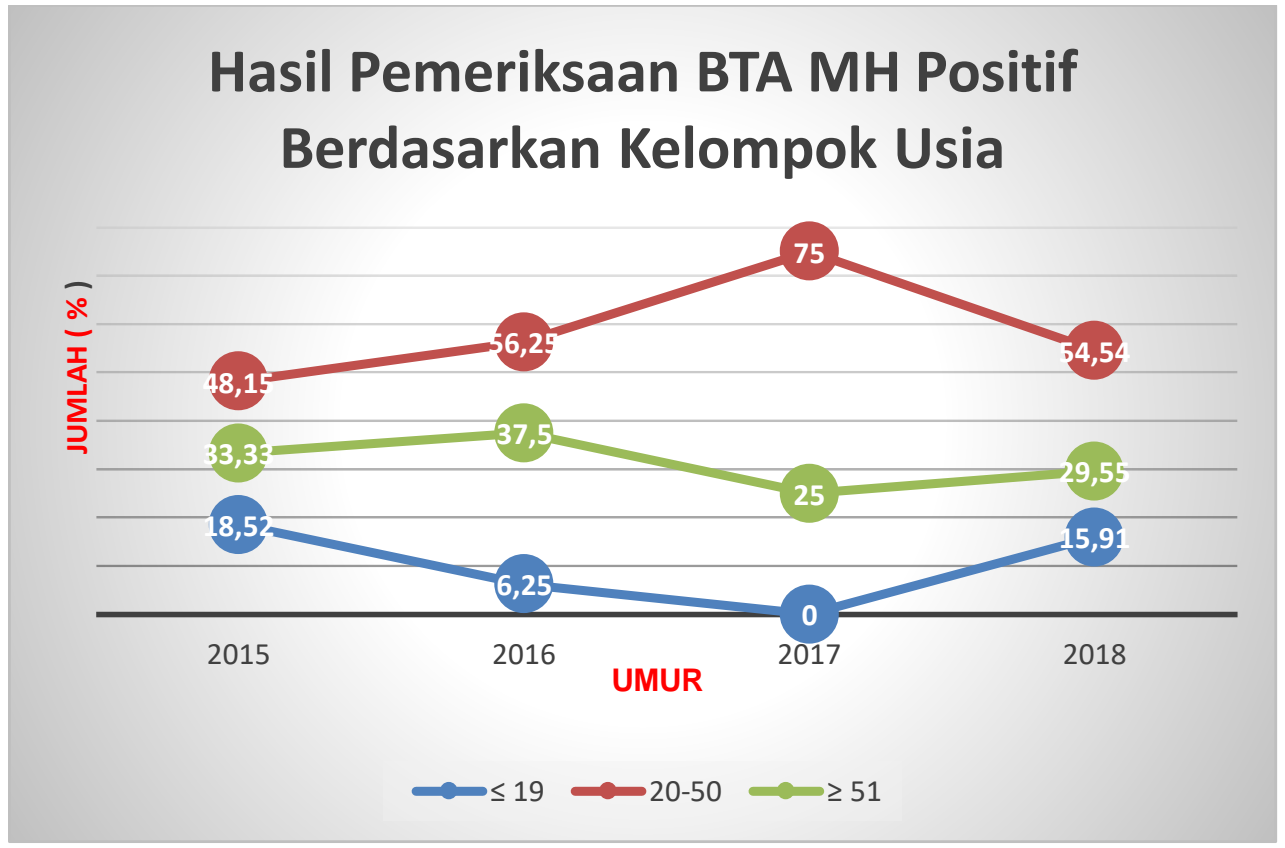

Gambar 3.

Persentase Pasien Baru Kusta dengan Hasil pemeriksaan BTA MH Positif Berdasarkan Kelompok Usia

Berdasarkan data di atas dapat diketahui bahwa berdasarkan kelompok usia dari tahun 2015 - 2018 dengan hasil BTA MH positif di dapatka terbanyak pada kelompok umur 20 - 50 tahun sebanyak $58(56,31 \%)$ pasien. 
Persentase pasien baru kusta berdsarkan jumlah lesi menurut WHO di RSUD Budhi ASih 2015 - 2018

Berdasarkan penggolongan tipe kusta di RSUD Budhi Asih dari tahun 2015 - 2018 ,dapat terlihat pada tabel hasil di bawah ini :

Tabel 4

Persentase Pasien Baru Kusta Berdasarkan Tipe Kusta

\begin{tabular}{|c|c|c|c|c|c|}
\hline \multirow{3}{*}{ Variabel } & \multicolumn{4}{|c|}{ Jumlah \& Persentase (\%) } & \multirow{3}{*}{ Jumlah } \\
\hline & \multicolumn{4}{|c|}{ Tahun } & \\
\hline & 2015 & 2016 & 2017 & 2018 & \\
\hline Tipe Kusta & & & & & \\
\hline Paubasiler (PB) & $21(31,3 \%)$ & $33(47,1 \%)$ & $28(42,4 \%)$ & $33(37,9 \%)$ & $115(39,66 \%)$ \\
\hline $\begin{array}{l}\text { Multibasiler } \\
\text { (MB) }\end{array}$ & $46(68,7 \%)$ & $37(52,9 \%)$ & $38(57,6 \%)$ & $54(62,1 \%)$ & $175(60,34 \%)$ \\
\hline Jumlah & $67(100 \%)$ & $70(100 \%)$ & $66(100 \%)$ & $87(100 \%)$ & $290(100 \%)$ \\
\hline
\end{tabular}

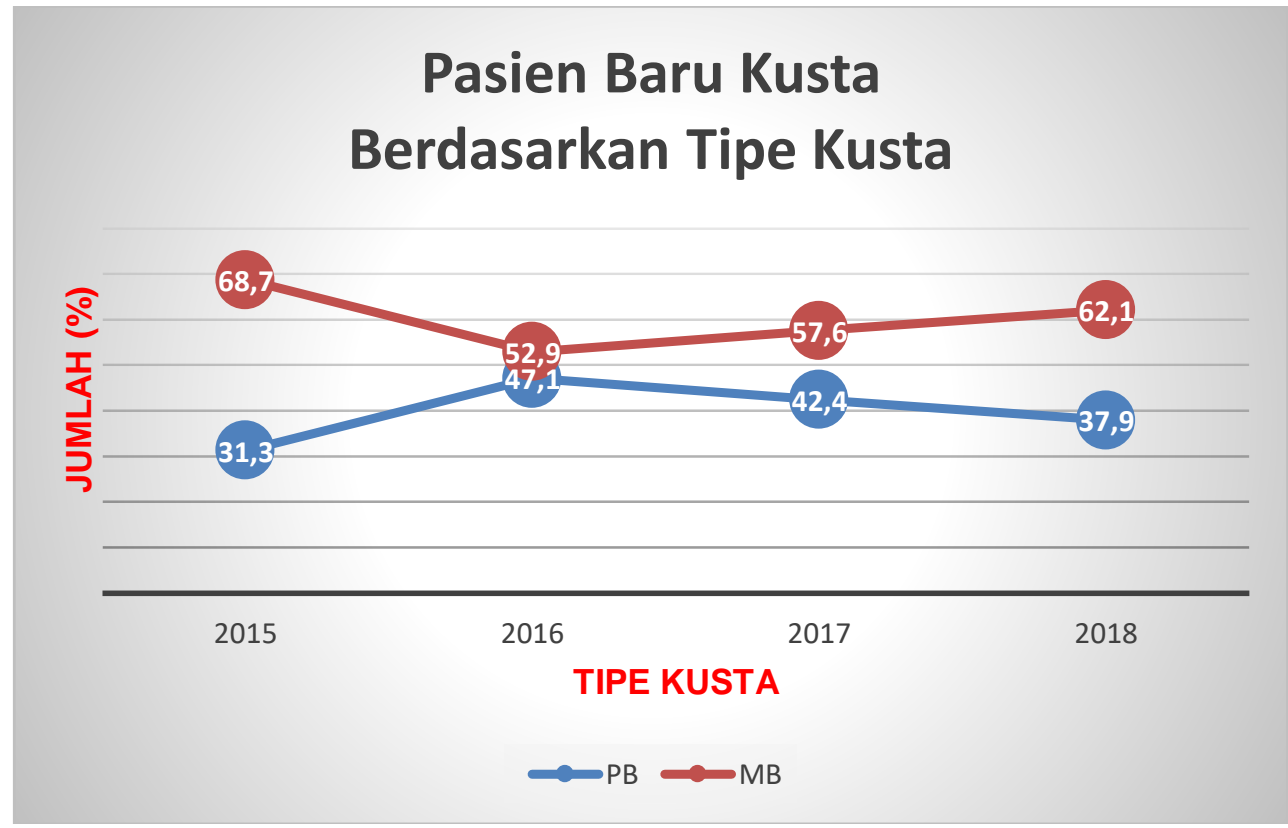

Gambar 4.

Persentase Pasien Baru Kusta Berdasarkan Tipe Kusta

Berdasarkan data di atas dapat diketahui bahwa dari tahun 2015 - 2018 dari 290 pasien yang memeriksakan BTA MH berdasarkan tipe kusta di dapat 115(39,66\%) tipe PB dan 175(60,34\%) tipe MB. 


\section{Pembahasan}

Persentase pasien baru kusta di RSUD Budhi Asih tahun 2015 - 2018

Berdasarkan penelitian yang di lakukan di RSUD Budhi Asih diperoleh terdapat 115(39,66\%) pasien dengan BTA MH positif selama periode 2015-2018 yang di lihat berdasarkan data rekam medis .Pada tabel 5 menunjukkan bahwa data kasus kusta baru yang memeriksakan BTA MH dalam setiap tahun , relatif masih dalam jumlah pasien yang tidak jauh berbeda. Pada tahun 2015 di peroleh $67(44,7 \%)$ pasien,terjadi penurunan pada tahun 2016 dan tahun 2017. Tetapi pada tahun 2018 terjadi peningkatan dalam jumlah pasien dengan hasil BTA MH positif.

Terjadi peningkatan jumlah penderita kusta baru. Hal ini kemungkinan disebabkan oleh peningkatan kejadian kusta seiring bertambahnya tahun, menurunnya kesadaran masyarakat terhadap kesehatan, dan menurunnya kesadaran untuk memperoleh pengobatan. Dapat disimpulkan bahwa pada saat ini penyakit kusta masih menjadi masalah kesehatan masyarakat yang perlu di perhatikan oleh pihak yang terkait.Hal ini sesuai dengan literatur yang menyatakan bahwa secara epidemiologis jumlah pasien kusta di masyarakat cenderung tetap bertahan, bahkan di Indonesia terdapat kecenderungan jumlah pasien baru kusta kembali meningkat.Saat ini di Indonesia menduduki peringkat ketiga di sunia dalam angka pasien kusta baru,setelah India dan Brazil.

Pasien yang positif kusta makin banyak karena penyakit kusta yang menular dan dapat menginfeksi pada saat seseorang dalam keadaan daya tahan tubuh yang lemah.

Persentase pasien baru kusta dengan BTA MH positif tahun 2015 -2018 berdasarkan jenis kelamin.

Pada penelitian ini ,jumlah pasien baru kusta dengan BTA MH positif berdasarkan jenis kelamin terbanyak berjenis kelamin laki -laki yaitu sebanyak $73(70,87 \%)$ pasien dan jenis kelamin perempuan sebanyak 30(29,13\%) pasien.

Jenis kelamin laki-laki lebih banyak daripada perempuan, hal ini sesuai dengan literatur yang bersumber dari Departemen Kesehatan RI tahun 2012 yang menyatakan bahwa kusta dapat mengenai laki-laki dan perempuan.Berdasarkan laporan, sebagian besar negara di dunia, menunjukkan prevalensi penyakit kusta lebih banyak pada pasien dengan jenis kelamin laki-laki . Laki-laki lebih banyak menderita kusta 
karena laki-laki cenderung lebih sering beraktivitas di luar rumah sehingga kemungkinan risiko tertular kusta lebih besar dari wanita (Darmaputra, 2009). Adanya kecenderungan tidak memakai pakaian di kehidupan sehari-hari pada laki-laki, diyakini meningkatkan kemungkinan risiko tertular kusta melalui kontak kulit .Pada penelitian lain disebutkan, laki-laki lebih banyak menderita kusta karena laki-laki kurang memperhatikan kebersihan diri dibandingkan dengan perempuan (Varkevisser, 2009). Berdasarkan dari hasil penelitian di RSUP Prof.Dr.R.D.Kandaou, jenis kelamin laki-laki lebih banyak menderita kusta $65 \%$ dari total penderita kasus baru. Hal ini kemungkinan karena laki-laki lebih sering bekerja di luar rumah daripada wanita, sehingga meningkatkan risiko tertular kusta. Namun, hal itu juga dipengaruhi oleh lingkungan pekerjaan dan keadaan sosial ekonomi penderita.

Persentase pasien baru kusta dengan BTA MH positif di RSUD Budhi Asih tahun 2015 - 2018 berdasarkan kelompok usia.

Dari data hasil penelitian pemeriksaan kusta dengan BTA MH positif berdasarkan kelompok usia menunjukkan bahwa kelompok usia 20 -50 tahun lebih banyak menderita penyakit kusta dibandingkan dengan kelompok usia $\geq 51$ tahun dan usia $\leq 19$ tahun. Dari hasil penelitian tersebut dapat diketahui bahwa penderita kusta usia dewasa lebih banyak daripada penderita usia anak-anak. Menurut Kumar, insiden kusta meningkat sesuai dengan peningkatan usia. Hal tersebut disebabkan oleh masa inkubasi kusta yang sangat lama. Seperti kita ketahui pada umumnya, usia 20 - 50 tahun merupakan usia produktif. Penyakit kusta dapat terjadi pada seseorang berusia produktif kemungkinan karena ruang gerak kegiatan sudah luas dan karena padatnya aktifitas menyebabkan daya tahan tubuh menurun dan dengan mudahnya terinfeksi kuman M. leprae. Hal ini sesuai menurut Prof.Dr.Muh.Dali Amiruddin,dr.Sp.KK(K), 2012:6 bahwa penularan dan perkembangan penyakit kusta hanya tergantung dari dua hal,yakni jumlah dan dan daya tahan tubuh penderita.

Dalam literatur lain disebutkan, usia tua meningkatkan risiko tertular kusta akibat menurunnya sistem imunitas seluler tubuh (Hargrave, 2010). Berdasarkan hasil penelitian di Rumah Sakit Kusta Kediri, penderita usia dewasa lebih banyak daripada penderita usia anak-anak dengan persentase lebih dari $90 \%$. 
Hal ini disebabkan oleh karena masa inkubasi M. leprae yang membutuhkan waktu lama sekitar 40 hari sampai 40 tahun, sehingga gambaran klinis muncul pada usia dewasa.

\section{Persentase pasien baru kusta berdasarkan jumlah lesi menurut WHO di RSUD Budhi Asih tahun} 2015 - 2018.

Dari data hasil penelitian pemeriksaan kusta berdasarkan tipe kusta menunjukkan bahwa data tipe kusta terbanyak adalah tipe multibasiler (MB) yaitu sejumlah 54(62,1\%) pasien, sedangkan tipe pausibasiler (PB) sejumlah 33(37,9\%). Hasil tersebut sesuai dengan penelitian Muctar di Poliklinik Kulit dan Kelamin RS Dr.Wahidin Sudirohusodo Makasar periode 2002-2003 didapatkan persentase tipe MB yaitu 91,7\%,sedangkan tipe PB 8,3\%. Pada penelitian di RSUD Dr.Soetomo Surabaya periode 2004-2006 didapatkan hasil yaitu tipe MB lebih banyak daripada tipe PB,karena tipe MB merupakan tipe kusta yang lebih mudah menular dibanidingkan tipe $\mathrm{PB}($ Amiruddin, 2003). Persentase penderita kusta tipe MB lebih besar daripada penderita kusta tipe PB dapat dipengaruhi oleh beberapa faktor,diantaranya adalah: genetik, tingkat virulensi bakteri, daya tahan tubuh penjamu, pengetahuan dan kesadaran penderita, cepatlambatnya seseorang untuk mencari pengobatan, jarak dan ketersediaan akses pelayanan kesehatan, keadaan sosial-ekonomi dan keteraturan minum obat MDT. Namun, faktor penyebab yang paling utama adalah daya tahan tubuh penjamu atau keadaan respon imun seluler seseorang. Bila respon imun selulernya baik, maka seseorang yang terinfeksi bakteri Mycobacterium leprae hanya akan bermanifestsi sebagai kusta tipe PB atau bahkan dapat sembuh sendiri. Namun, bila respon imun selulernya buruk, maka akan bermanifestasi sebagai kusta tipe MB.

\section{SIMPULAN}

Berdasarkan hasil penelitian terhadap hasil pemeriksaan laboratorium di RSUD Budhi Asih tahun 2015 - 2018 dengan total 290 pasien kusta baru rawat jalan yang melakukan pemeriksaan BTA MH didapatkan: Persentase pasien baru kusta diperoleh hasil pemeriksaan BTA MH positif mencapai 103(35,52\%) pasien dan hasil pemeriksaan BTA MH negatif mencapai 187(64,48\%) pasien. Persentase pasien baru kusta dengan BTA MH positif berdasarkan jenis kelamin diperoleh hasil 73(70,87\%) berjenis kelamin laki-laki dan 30(29,13\%) berjenis kelamin perempuan. Persentase pasien baru kusta 
dengan BTA MH positif berdasarkan kelompok usia diperoleh 13(12,62\%) pasien dengan usia $\leq 19$ tahun , 58(56,31\%) pasien dengan usia 20-50 tahun dan 32(31,07\%) pasien dengan usia $\geq 51$ tahun. Persentase pasien baru kusta berdasarkan jumlah lesi yang di kelompokkan berdasarkan tipe kusta diperoleh tipe kusta terbanyak adalah tipe MB, dengan hasil tipe PB 115(39,66) pasien dan tipe MB $175(60,34 \%)$ pasien.

\section{UCAPAN TERIMA KASIH}

Penulis mengucapkan terima kasih kepada Kepala Laboratorium RSUD Budhi Asih dan Prodi D III Analis Kesehatan Universitas MH Thamrin berperan serta dalam penelitian ini.

\section{DAFTAR PUSTAKA}

1. Andareto, O., Penyakit Menular di Sekitar Anda, Rini (Ed), Pustaka Ilmu Semesta, Jakarta, 2015.

2. Ayu Maharani, Penyakit Kulit, Perawatan, Pencegaha \& Pengobatan, Pustaka Baru press, Yogyakarta 2015

3. Departeman Kesehatan RI, Ditjen PPM \& PL, Pedoman Program P2 Kusta bagi petugas Puskesmas, Sub Direktorat Kusta dan Frambusia Direktorat P2ML, Jakarta, 1995.

4. Dr. Moch. Irfan Hadi, M. KL, Mei Lina Fitri Kumalasari, M.Kes, Kusta Stadium Subklinis ,Faktor Risiko dan Permasalahannya,Surabaya,2017

5. Dr.Flora Ramona Sigit Prakoeswa,M.Kes.,Sp.KK, Buku Ajar Kusta,Surakarta,2018

6. Herlina Soumilena,Standy Soeliongan,Velma Buntuan.,Gambaran pemeriksaan mikroskopik Basil Tahan Asam pada pasien diagnosa klinik lepra di poli penyakit kulit dan kelamin di BLU RSU Prof.Dr.R.D.Kandaou Manado, Jurnal e-Biomedik(eBM),2014

7. I Gusti Nyoman Darma Putra, Nurul Fauzi, Indropo Agusni., Kecacatan pada Penderita Kusta Baru di Divisi Kusta URJ Penyakit Kulit dan Kelamin RSUD Dr. Soetomo Surabaya Periode 2004-2006

8. Jawetz,E; Melnick,J.L; dan Eldelberg,E.A., Mikrobiologi Kedokteran, Edisi 25, EGC, Jakarta, 2010 .

9. Kementerian Kesehatan RI,Direktorat Jenderal Pengendalian Penyakit dan Penyehatan Lingkungan, Pedoman Nasional Program Pengendalian Penyakit Kusta,2012

10. Prof.Dr.Muh.Dali Amiruddin, dr.SpPK(K), Penyakit Kusta, Brilian Internasional, Surabaya.2012

11. Pusat Data Informasi Kementerian Kesehatan RI: 2018, Kusta, Hapuskan stigma dan diskriminasi terhadap kusta.

12. Rahman,A.M., Aibidin,S., Abdul,R.A., Kajian terhadap Penolakan Status Penderita Kusta di Wilayah Kerja Puskesmas Tellu Siattinge Kecamatan Tellu Siattinge Kabupaten Bone 2008, Jurnal Direktorat Politeknik Kesehatan Makassar, Makassar, 2013. 
13. Ross, W.Felton, Penyakit Kusta untuk Petugas Kesehatan, diterjemahkan oleh Paulus W, Halim, Gramedia, Jakarta, 1989.

14. Syahrurachman,A., dkk., Mikrobiologi Kedokteran, Edisi Revisi, Binarupa Askara, Jakarta, 1994.

15. World Health Organization (WHO) Manual of Basic Techniques for a health Laboratory,Alih bahasa : Chairlan,Estu Lestari,Editor Edisi Bahaasa Indonesia,Albertus Agung Mohade,2011) pedoman teknik dasar untuk laboratorium kesehatan Edisi ke 2,Penerbit Buku Kedokteran EGC jakarta.

16. Yudied,A.M,dkk., Kajian Pengendalian Potensial Faktor Risiko Penularan Penyakit Kusta dan Intervensinya di Puskesmas Pragaan Kabupaten Sumenep tahun 2007, Jurnal Buletin Human Media, 2008. 